\title{
Corporate Social Responsibility Versus Financial Performance:
}

\author{
Critical Review Small and Medium Enterprises (SMEs)
}

\author{
Rudi Salam*, Cacik Rut Damayanti, Kemal Sandi \\ Department of Administration Science \\ Universitas Brawijaya \\ East Java, Indonesia \\ *rudisalam@student.ub.ac.id, cacik@ub.ac.id, \\ kemalsandi27@gmail.com
}

\author{
Haedar Akib \\ Department of Public Administration \\ Universitas Negeri Makassar \\ Makassar, Indonesia \\ haedarakib@unm.ac.id
}

\author{
A. Octamaya Tenri Awaru \\ Department of Sociology \\ Universitas Negeri Makassar \\ Makassar, Indonesia \\ a.octamaya@unm.ac.id
}

\begin{abstract}
The pro contract between CSR and financial performance in companies has become a hot topic in the debate of researchers regarding literature and empirical studies. In large companies, CSR has a positive impact on financial performance. However, experts argue that CSR will actually have a negative impact on financial performance. critique of these two aspects, commenting on every condition experienced in Small and Medium Enterprises. This debate, has provided very meaningful nuances from various parts of the world both in countries from the continent of Asia, America, Europe, Africa. Various parts of the world have characterized the debate between CSR and financial performance. Empirical studies that have been carried out from various developed and developing countries show that CSR has a positive and significant impact on financial performance in Small and Medium Enterprises. Therefore, it is hoped that we will examine further the development of an increasingly complex business world.
\end{abstract} SMEs

Keywords-CSR, financial performance, firm performance,

\section{INTRODUCTION}

Industrial competition will have an impact on the relationship of Corporate Social Responsibility (CSR) with financial performance [1]. Therefore, companies must prepare themselves in facing any increasingly fierce industry competition. On the other hand, companies face obstacles both in terms of financial, risk and earnings quality to create corporate value to CSR activities in the context of the sustainability of their businesses [2]. In addition, various experts explain that CSR has had a positive impact on a company's financial performance [1,3-8].
The discussion about CSR activities carried out by the company has become a debate in order to improve company performance. According to Hadj [9] revealed that CSR is a company's strategy to be famous and able to compete with other companies. This can apply to large companies and have grown in maintaining their companies to survive [7]. In contrast to small and medium-sized businesses that have financial limitations in running a business [8]. However, according to Jahmane and Gaies [10], Sardana et al. [11] revealed that there is no difference between large companies and small companies in the implementation of CSR to improve the company's financial performance.

Good financial actors are companies that display good accountability, while at the same time showing the ability to disclose the structure of CSR concentrated disclosure to definitive stakeholders. The strategy for maximizing the positive relationship between CSR and financial performance is to conduct successful reporting for business organizations [12]. While the results of Bhattacharyya and Rahman [13] revealed that CSR expenditure contributed to confirm financial performance. Likewise, SMEs can minimize their capital constraints by starting CSR practices, which can ultimately translate into financial performance [3]. Another opinion revealed that CSR should not increase company costs in conducting business competition [14-17]. Therefore, the authors are interested in conducting a study of CSR versus financial performance in the field of Small and Medium Enterprises. 


\section{MethodS}

This article aims to determine the relationship between CSR and financial performance. In addition, I want to know the theoretical debate between the two topics. In addition, the writer presents empirical research on the two variables discussed. The author makes two stages in the article writing method, namely first, reviewing various sources, both proceedings and journals, on the debate between CSR and financial performance in UKM. Met The author determines two stages in the writing method. In the selection process, such as Emerald Group Publishing, Academy of Management, Elsevier BV, Sage Publication, JSTOR, Wiley Online, and several other publishers. Second, the authors compile relevant papers in accordance with the topic of CSR and Financial Performance with the aim that to find out the debate on the problems faced in SMEs. Article selection obtained. Following the article selection stage, the authors obtained 36 titles consisting of 16 studies, 18 literature reviews, and 2 conference proceedings.

\section{Debate Theory of CSR on Financial Performance}

Limited studies of CSR have been carried out before the 1960s. During the 1960s, the CSR literature underwent developments in business financial studies [18]. In the free market era in the 1970s [18] work was integrated with CSR characteristics. Many writers at this time focused on CSR processes that did not conflict with business interests. Friedman believes that social involvement is justified while serving the company in the long run. Aupperle et al. [14] also recognized the need for comprehensive characterization of CSR and developed a framework for understanding various CSR concepts. The debate over CSR theory certainly has an impact on financial performance. However, not a few also do criticism and response from the relevance of the study [19].

\section{A. Criticism of CSR Theory of Financial Performance}

The various authors' hypotheses regarding the relationship of CSR to financial performance have different thoughts from one another. This can be seen from the positive impact seen from the implementation of CSR on a company's financial performance. However, on the other hand other companies have a negative impact arising from the relationship between the two. As a result, the resulting efficiency and non-efficiency.

Proponents of CSR argue that companies benefit more by operating with a long-term view of the organization and their role in society than they do by focusing only on their own short-term profits [20,21]. Whereas politicians argue that CSR distracts from the fundamental economic role of business, which is producing finance [22]. CSR activities also received criticism and requests from stakeholders who sought social acceptance and legitimacy $[23,24]$.

Mikołajek-Gocejna [25] expressed criticism that there is no positive relationship between CSR and financial performance. This is because the company's finances must be taken into account in carrying out CSR activities because at the level of the medium-sized companies down there certainly have problems in funding difficulties. In contrast to companies that have high funding, they have thought carefully of every funding they spend. Other opinions, also following financial thinking that consider spending with CSR, have not been able to consider CSR as a decision criterion with regard to their alternatives for investment and consumption [26-29].

\section{B. Response to CSR Theory Criticism of Financial Performance}

The company's specific social capital, built through CSR activities, increased public confidence unexpectedly, namely the 2008-2009 financial crisis [26]. Specifically, found that companies with high CSR ratings outperformed companies with low CSR ratings. They found that excess returns were higher for companies headquartered in areas where individuals trusted more. There is no difference in the performance of stock returns between high and low CSR companies during the recovery period after the crisis.

Collectively, these results indicate that the increase in social capital resulting from CSR activities is problematic especially in the period when trust in the company has generally been eroded, and that during normal times any benefit from social capital has been embedded in the company's share price. The lack of returns in the post-crisis period shows that being trustworthy remains important, which is in line with survey data reporting continued low levels of trust in companies and the stock market. The study examined the mechanism by which a higher level of CSR can produce excess returns during a crisis and found that high CSR companies benefit through higher profitability, margins, sales growth, and employee productivity relative to low CSR companies. Some of these effects also persist in the post-crisis period, but to a lesser extent than economic and statistical significance, again consistent with survey evidence which shows that confidence is still relatively low.

Overall, our results show that building company-specific social capital can be considered an insurance policy that pays off when investors and the economy as a whole face a severe crisis of confidence. Our work also shows that social capital, in addition to financial capital, can be an important determinant of company performance, and identify the circumstances in which CSR can benefit company value. several proxies to measure the financial health of a company and, as such, its ability to withstand a severe decline in the economy: Cash Withholding (cash and securities divided by assets), Short-term Debt (debt in current liabilities divided by assets), Long-term Debt (longterm debt divided by assets), and profitability (operating income divided by assets). During a crisis, profitable and cashrich companies with low debt can continue to invest, while other companies may be forced to cut investment, especially if they have short-term debt that is due during the crisis [26-29].

The response expressed by Bambang et al. [30] states that financial performance has no effect on firm value. This may be because not all companies will distribute their income to shareholders. To grow and develop, companies will need more 
funds for future financing sources in addition to funding from debt and equity. If the company's profitability increases, it is likely that managers will use net income to expand their business and expand rather than share profits with shareholders. Therefore, investors cannot make financial indicators as a single indicator in making investment decisions, but must also consider social, environmental, political and management policy factors.

The relationship between the two aspects, namely CSR and Financial performance provides a perspective from each research or literature. The pros and cons conveyed responded to the reality and conditions that made it possible to have a positive connection and not to have a negative or neutral relationship with each other. Likewise, CSR and financial performance have a significant positive relationship when implemented by companies at the middle and upper levels. However, at the lower middle level it is still difficult to predict the relationship between one another. In other conditions, such as the monetary crisis, an outbreak in a country is certainly very influential in the sustainability of a company if it is related to both aspects.

\section{EMPIRICAL STUDY OF CSR ON FINANCIAL PERFORMANCE IN THE FIELD OF SMALL AND MEDIUM ENTERPRISES (SMES)}

Studies on the relationship between CSR and financial performance have been widely studied. However, the study of Small and Medium Enterprises (SMEs) is still very limited. This makes the study interested. In order to provide an overview of the empirical study of the linkages of CSR indicators and financial performance can be seen in table 1 .

TABLE I. EMPIRICAL STUDY OF CSR, FINANCIAL PERFORMANCE, AND SMALL AND MEDIUM ENTERPRISES (SMES) STUDIES [18].

\begin{tabular}{|l|l|}
\hline \multicolumn{1}{|c|}{ Writer (years) } & \multicolumn{1}{c|}{ Research sites } \\
\hline Arend [31] & USA \\
\hline Fonseca \& Ferro [32] & Portugal \\
\hline Besser [33] & Europe \\
\hline Choongo [34] & Zambia \\
\hline El Baz et al. [35] & France, Morocco \\
\hline Herrera Madueño et al. [36] & Spain \\
\hline Li et al. [37] & China, Finland \\
\hline Martínez-Martínez et al. [38] & Spain \\
\hline Park \& Ghaur [39] & Korea \\
\hline Popa \& Salanta [40] & Romania \\
\hline Sen \& Cowley [41] & Australia \\
\hline Srichatsuwan [42] & USA \\
\hline Stoian \& Gilman [43] & United Kingdom \\
\hline Szczanowicz \& Saniuk [44] & Poland \\
\hline Tang \& Tang [45] & China \\
\hline Torugsa et al. [46] & Australia \\
\hline
\end{tabular}

Table 1 explains that empirical studies from various countries made a large contribution in the relationship between CSR and Financial Performance. The literature, there is still a gap between the financial, social and environmental goals of SMEs. First, there are still inconsistencies in the characterization of CSR, which leads to a diversity of models and steps to investigate CSR relationships. The most commonly measured social performance variable is the environment, followed by employees, communities, and customers, with suppliers and shareholders gathering a relatively small segment. Williams [18] argue that the lack of standardization of measurement is a prominent limitation of CSR empirical procedures. Second, the determination of control variables and intervening variables varies over the spectrum of CSR-financial performance studies. Measures of financial performance, including single, multiple, and consolidated indicators, vary widely in various literatures, making generalized synthesis of models difficult [42]. Third, the literature continues to be under-represented in SME CSRfinancial performance studies. Most CSR-financial performance investigations remain in the business sector of large companies $[42,47]$. Fourth, there are inconsistencies in the application of theoretical frameworks in CSR research. The prevailing theme applied in CSR studies continues to be a stakeholder theory over shareholder theory. The introduction of social capital, social welfare, competition, and institutional theory in relation to stakeholder theory, which can spur the creation of shared values $[18,45]$, has formed gaps in social performance literature that guarantees further exploration. Fifth, there appears to be a significant gap in research investigating the comparison of SMEs from various sectors and the relationship between CSR-financial performance. The work of Williams [18] represented the only study found on this specific subject and was an inspiration for this investigation. Sixth, most empirical studies of CSR-financial performance have been correlative and involve several regression versions of structural equation modeling (SEM) [18]. Sixth, there is a lack of literature in investigations involving the relationship between the length of time an SME company has existed or the length of time their relationship with the local community and the CSR-financial performance relationship. Finally, the study literature on CSR-financial performance-SMEs uses less data from America when compared to the literature using European, Australian and Asian data.

Empirical studies from various countries have an impact on the pros and cons of CSR on financial performance in companies in the SME field. In developed countries, it has had a positive impact between CSR and financial performance. After conducting research in developing countries, it has had a positive and significant impact on the linkages of these two aspects. This proves that, the positive impacts arising from various countries both developed and developing countries have a significant impact. Although in the empirical research, it is still limited from the empirical studies studied and needs to be studied in more depth from various countries with more specific clusters.

Based on between CSR and financial performance has canceled the polemic in every company. However, also, to be an amplifier in realizing a company that can develop well. Therefore, in the new Normal Pandemic era, it is hoped that every UKM will be able to make CSR as an amplifier in supporting the financial performance of each company. 


\section{CONCLUSION}

CSR studies have an impact on company development, especially in financial performance. In the process of development experienced pros and cons both positive and negative impacts on the relationship of theory and empirical studies. In the long run, the association of these concepts will have a positive impact on the company. The positive impact caused by CSR will be public trust in the company. As a result, an increase in corporate financial performance will automatically increase. Such is the case in crisis conditions that have been experienced with a high level of trust. However, other opinions have a negative impact due to spending with CSR, have not been able to provide high profitability benefits, margin of sales growth. This is caused by the level of mediumsized companies experiencing difficulties in funding as well as those experienced by Small and Medium Enterprises. However, after conducting empirical studies from various countries both in America, Europe, Asia, Australia, Africa, it shows that from both aspects, it has had a positive impact between CSR and Financial performance. Therefore, it is expected to require more in-depth study and research from more specific clusters in testing the linkages of the two aspects.

\section{ACKNOWLEDGMENT}

Thank you to Universitas Brawijaya for facilitating us in publishing literature review articles. We hope that this article will be of use to various groups in developing the world of education and the world of business.

\section{REFERENCES}

[1] W. Long, S. Li, H. Wu, and X. Song, "Corporate social responsibility and financial performance: The roles of government intervention and market competition," Corp. Soc. Responsib. Environ. Manag., vol. 27, no. 2, pp. 525-541, 2020.

[2] S. Ronald, S. Ng, and F. Eduardus, "Corporate Social Responsibility as Economic Mechanism for Creating Firm Value," Indones. J. Sustain. Account. Manag., vol. 3, no. 1, pp. 22-36, 2019.

[3] O. S. Agyemang and A. Ansong, "Corporate social responsibility and firm performance of Ghanaian SMEs," J. Glob. Responsib., vol. 8, no. 1, pp. 47-62, 2017.

[4] E. Akben-Selcuk, "Corporate social responsibility and financial performance: The moderating role of ownership concentration in Turkey," Sustain., vol. 11, no. 13, 2019.

[5] P. L. Cochran and R. A. Wood, "Corporate Social responsibility and Financial Performance," Acad. Manag. J., vol. 27, no. 1, pp. 42-56, 1984.

[6] J. B. Mcguire, A. Sundgren, T. Schneeweis, and J. B. Mcguire, "Corporate Social Responsibility and Financial Performance," Acad. Manag. J., vol. 31, no. 4, pp. 854-872, 1988

[7] Y. Rhou, M. Singal, and Y. Koh, "CSR and financial performance: The role of CSR awareness in the restaurant industry," Int. J. Hosp. Manag. vol. 57, pp. 30-39, 2016

[8] H. Youn, N. Hua, and S. Lee, "Does size matter? Corporate social responsibility and firm performance in the restaurant industry," Int. J. Hosp. Manag., vol. 51, pp. 127-134, 2015.
[9] T. B. Hadj, "Effects of corporate social responsibility towards stakeholders and environmental management on responsible innovation and competitiveness," J. Clean. Prod., vol. 250, pp. 119490, 2020.

[10] A. Jahmane and B. Gaies, "Corporate social responsibility, financial instability and corporate financial performance: Linear, non-linear and spillover effects - The case of the CAC 40 companies," Financ. Res. Lett., no. February, pp. 101483, 2020.

[11] D. Saranda, N. Gupta, V. Kumar, and M. Terziovski, "CSR 'sustainability' practices and firm performance in an emerging economy," J. Clean. Prod., vol. 258, pp. 120766, 2020.

[12] H. Yusoff, S. S. Mohamad, and F. Darus, "The Influence of CSR Disclosure Structure on Corporate Financial Performance: Evidence from Stakeholders' Perspectives," Procedia Econ. Financ., vol. 7, no. Icebr, pp. 213-220, 2013.

[13] A. Bhattacharyya and M. L. Rahman, "Mandatory CSR expenditure and firm performance," J. Contemp. Account. Econ., vol. 15, no. 3, pp. 100163, 2019

[14] K. E. Aupperle, A. B. Carroll, and J. D. Hatfield, "an Empirical Examination of the Relationship Between Corporate Social Responsibility and Profitability.," Acad. Manag. J., vol. 28, no. 2, pp. 446-463, 1985.

[15] M. Friedman, "The social responsibility of business is to increase its profits," Corp. Soc. Responsib., pp. 31-35, 2017

[16] M. C. Jensen, "Value maximization, stakeholder theory, and the corporate objective function," Bus. ethics Q., pp. 235-256, 2002

[17] A. McWilliams and D. Siegel, "The role of money managers in assessing corporate social reponsibility research," J. Invest., vol. 6, no. 4, pp. 98-107, 1997.

[18] R. O. Williams, "Corporate Social Responsibility and Financia Performance of U.S. Manufacturing and Service Small- and MediumSized Enterprises," 2020.

[19] W. Lu, K. W. Chau, H. Wang, and W. Pan, “A decade's debate on the nexus between corporate social and corporate financial performance: A critical review of empirical studies 2002-2011," J. Clean. Prod., vol. 79, pp. 195-206, 2014.

[20] N. Hoque, A. R. A. Rahman, R. I. Molla, A. H. M. Noman, and M. Z. H. Bhuiyan, "Is corporate social responsibility pursuing pristine business goals for sustainable development?," Corp. Soc. Responsib. Environ. Manag., vol. 25, no. 6, pp. 1130-1142, 2018

[21] H. Chwistecka-Dudek, "Corporate Social Responsibility: Supporters vs opponents of the concept," in Forum Scientiae Oeconomia, 2016, vol. 4, no. 4 , pp. 171-179.

[22] C. Flammer and P. Bansal, "Does a long-term orientation create value? Evidence from a regression discontinuity,” Strateg. Manag. J., vol. 38, no. 9, pp. 1827-1847, 2017.

[23] L. L. Benites-Lazaro and N. A. Mello-Théry, "CSR as a legitimatizing tool in carbon market: Evidence from Latin America's Clean Development Mechanism,” J. Clean. Prod., vol. 149, pp. 218-226, 2017.

[24] A. Vollero, F. Conte, A. Siano, and C. Covucci, "Corporate socia responsibility information and involvement strategies in controversia industries," Corp. Soc. Responsib. Environ. Manag., vol. 26, no. 1, pp. 141-151, 2019

[25] M. Mikołajek-Gocejna, "The relationship between corporate socia responsibility and corporate financial performance-Evidence from empirical studies," Comp. Econ. Res., vol. 19, no. 4, pp. 67-84, 2016.

[26] K. V Lins, H. Servaes, and A. Tamayo, "Social capital, trust, and firm performance: The value of corporate social responsibility during the financial crisis,” J. Finance, vol. 72, no. 4, pp. 1785-1824, 2017.

[27] R. Duchin, O. Ozbas, and B. A. Sensoy, "Costly external finance, corporate investment, and the subprime mortgage credit crisis," J. financ. econ., vol. 97, no. 3, pp. 418-435, 2010.

[28] H. Amiraslani, K. V Lins, H. Servaes, and A. Tamayo, "A matter of trust? The bond market benefits of corporate social capital during the financial crisis," 2017

[29] E. Almeida, “Econometria espacial,” Campinas-SP. Alínea, 2012. 
[30] S. Bambang, P. Elen, and K. Andi, "The company's policy, firm performance, and firm Value: An empirical research on Indonesia Stock Exchange,” Am. Int. J. Contemp. Res., 2012.

[31] R. J. Arend, "Social and Environmental Performance at SMEs: Considering Motivations , Capabilities , and Instrumentalism," pp. 541561, 2014.

[32] L. M. Fonseca and R. L. Ferro, "Does it pay to be social responsible? Portuguese SMEs feedback," vol. 12, no. 2, pp. 487-505, 2016.

[33] T. L. Besser, "The consequences of social responsibility for small business owners in small towns," Bus. Ethics A Eur. Rev., vol. 21, no. 2, pp. 129-139, Apr 2012.

[34] P. Choongo, "A longitudinal study of the impact of corporate social responsibility on firm performance in SMEs in Zambia," Sustain., vol. 9, no. 8, 2017.

[35] J. El Baz, I. Laguir, M. Marais, and R. Staglianò, "Influence of national institutions on the corporate social responsibility practices of small-and medium-sized enterprises in the food-processing industry: Differences between France and Morocco," J. Bus. Ethics, vol. 134, no. 1, pp. 117133, 2016.

[36] J. Herrera Madueño, M. Larrán Jorge, I. Martínez Conesa, and D. Martínez-Martínez, "Relationship between corporate social responsibility and competitive performance in Spanish SMEs: Empirical evidence from a stakeholders' perspective," BRQ Bus. Res. Q., vol. 19, no. 1, pp. 55-72, 2016.

[37] N. Li, A. Toppinen, and M. Lantta, "Managerial perceptions of SMEs in the wood industry supply chain on corporate responsibility and competitive advantage: evidence from China and Finland," J. Small Bus. Manag., vol. 54, no. 1, pp. 162-186, 2016.
[38] D. Martínez-Martínez, J. H. Madueño, M. L. Jorge, and M. P. L. Sancho, "The strategic nature of corporate social responsibility in SMEs: A multiple mediator analysis,” Ind. Manag. Data Syst., 2017.

[39] B. Il Park and P. N. Ghauri, "Determinants influencing CSR practices in small and medium sized MNE subsidiaries: A stakeholder perspective," J. World Bus., vol. 50, no. 1, pp. 192-204, 2015.

[40] M. Popa and I. Salanta, "Corporate social responsibility versus corporate social irresponsibility,” Manag. Mark., vol. 9, no. 2, pp. 137, 2014.

[41] S. Sen and J. Cowley, "The relevance of stakeholder theory and social capital theory in the context of CSR in SMEs: An Australian perspective," J. Bus. Ethics, vol. 118, no. 2, pp. 413-427, 2013.

[42] S. Srichatsuwan, "Corporate social responsibility and performance: A study of small businesses in the United States." Alliant International University, Alliant School of Management, San Diego, 2014.

[43] C. Stoian and M. Gilman, "Corporate social responsibility that 'pays': A strategic approach to CSR for SMEs," J. Small Bus. Manag., vol. 55, no. 1, pp. 5-31, 2017.

[44] J. Szczanowicz and S. Saniuk, "Evaluation and reporting of CSR in SME sector," Management, vol. 20, no. 1, pp. 96-110, 2016.

[45] Z. Tang and J. Tang, "The impact of competitors-firm power divergence on Chinese SMES'environmental and financial performance," J. Bus. Ethics, vol. 136, no. 1, pp. 147-165, 2016.

[46] N. A. Torugsa, W. O’Donohue, and R. Hecker, "Proactive CSR: An empirical analysis of the role of its economic, social and environmental dimensions on the association between capabilities and performance," $\mathrm{J}$. Bus. Ethics, vol. 115, no. 2, pp. 383-402, 2013.

[47] F. Perrini, "SMEs and CSR theory: Evidence and implications from an Italian perspective," J. Bus. ethics, vol. 67, no. 3, pp. 305-316, 2006. 